\title{
THE MOTION FOR ACQUITTAL: A NEGLECTED SAFEGUARD*
}

The Anglo-American trial has traditionally been an adversary proceeding. A fundamental characteristic of such a trial is that the party who brings the action has the initial burden of producing evidence in support of his claim. ${ }^{1}$ A defendant-civil or criminal-need not offer a defense until this burden has been satisfied. Once the party who has brought the action produces sufficient evidence to carry his case to the jury, however, a defendant remains mute at his peril since a verdict may now be returned against him. ${ }^{2}$ Theoretically, a defendant can test the sufficiency of the evidence at the close of his opponent's case-in-chief by a motion for directed verdict in a civil trial or by a motion for acquittal in a criminal trial. ${ }^{3}$ If at this time the evidence is insufficient, the court is supposed to terminate the action in favor of the defendant. ${ }^{4}$ In practice, however, such a motion is often denied despite the insufficiency of the evidence.

The motion for acquittal in the criminal trial and its civil counterpart, the motion for directed verdict, are the products of an evolutionary trend which has increased the supervisory role of the judge over the trial process. The demurrer to the evidence was the first method by which a judge could withdraw a civil case from the jury and decide it with finality; both parties, however, had to consent to the withdrawal. ${ }^{5}$ The common law motion for non-suit

*An earlier version of this Comment was submitted in satisfaction of the writing requirement of the Yale Law School's Divisional Program, Procedure and Advocacy Division, 1960-1961. The Law Journal wishes to thank Professor Abraham S. Goldstein for bringing this paper to the Editors' attention.

1. 9 WigMrore, EVIDENCE $\$ 2511$ (3d ed. 1940). See generally id. §§ 2487, 2494.

2. Id. § 2487.

3. The term "motion for acquittal" is used here to include all devices with the same purpose and the same effect. E.g., FED. R. CRIM. P. 29 (motion for judgment of acquittal); ARIz. R. Crim. P. 270 (motion for directed verdict); State v. Bonomo, 173 Kan. 675, 250 P.2d 833 (1952) (demurrer to the evidence); Shiflett v. State, 262 Ala. 337, 78 So. 2d 805 (1955) (motion to exclude the evidence).

4. The question of sufficiency is most important when the state's case rests in part on circumstancial evidence since, where there is direct testimony of a fact, the jury is the sole judge of credibility unless the testimony is "inherently improbable," People v. Carvalho, 112 Cal. App. 2d 482, 489, 246 P.2d 950, 955 (1952), or "incredible as a matter of law," State v. Merryman, 79 Ariz. 73, 283 P.2d 239 (1955).

5. The earliest reported use of the demurrer to the evidence was Tikford v. Caldwell, Y.B. 34 Hen. VI, 36, pl. 7 (1456), in Thayer, Cases on Evidence 201 (2d ed. 1900). The demurrer was a risky tool because, where denied, judgment was ordered against the moving party. By the end of the 18th century the demurring party had to list in writing every fact admitted. Gibson v. Hunter, 2 H. Bl. 187, 126 Eng. Rep. 499 (1793). For a detailed historical analysis, see King, Trial Practice-Dennurrer Upon Evidence as a Device for Taking a Case from the Jury, 44 Mirch. L. Rev. 468 (1945); Thayer, A Preliminary Treatise on EVIDENCE 234-39 (1898). 
came later and as adopted in the United States it empowered the judge to dismiss an action on the motion of the defendant alone but left the plaintiff free to reinstitute his suit. ${ }^{6}$ In the 19 th century judges began to utilize the directed verdict in civil cases, granting final judgment on the motion of the defendant when the proponent's case failed the test of sufficiency. ${ }^{7}$ The motion for judgment of acquittal in criminal cases came still later and was probably influenced by these earlier developments in the civil trial. ${ }^{8}$

In the criminal trial the efficacy of the defendant's motion for acquittal at the close of the prosecution's case is severely limited by the refusal of almost all appellate courts to review denial of the motion if the defendant later introduced evidence on his own behalf. ${ }^{9}$ The accused who chooses to present a defense may of course renew his motion for acquittal after both sides have rested. ${ }^{10}$ At that time, however, the trial and appellate courts will consider all the evidence of guilt in ruling on the motion, including any incriminating facts supplied by the defendant himself. ${ }^{11}$ The courts hold that an accused who presents a defense has "waived" his right to a review of the sufficiency of the

6. Restatemients, Judgnents $\$ 53$ (1942); Field \& Kaplan, Materdals on Civil Procedure 573 (1953). See Annot., 79 A.L.R. 688 (1932) (conditions under which plaintiff can take voluntary non-suit).

7. [T] he defendant's counsel requested the court to instruct the jury, "that, if the evidence is believed by the jury to be true, the plaintiff is not entitled to recover." This instruction was given by the court ... [T] he practice of granting an instruction like the present, which makes it imperative upon the jury to find a verdict for the defendant ... has in many States superseded the ancient practice of a demurrer to evidence.

Parks v. Ross, 52 U.S. (11 How.) 316, $372-73$ (1850).

8. The early cases directing acquittal did so without citing any authority but apparently assumed such power was inherent in the judge's role as presiding officer. See United States v. Fullerton, 25 Fed. Cas. 1225 (No. 15176) (C.C.S.D.N.Y. 1870); Commonwealth v. Merrill, 80 Mass. (14 Gray) 415, 417-18 (1860); see also United States v. Anthony, 24 Fed. Cas. 829 (No. 14459) (C.C.N.D.N.Y. 1873) which relied on Fullerton, supra, in directing the jury to convict the defendant. But see Annot., 72 A.L.R. 899 (1931) (so long as accused pleads "not guilty" he is entitled to have the prosecutor's case submitted to the jury).

9. See, e.g., Corbin v. United States, 253 F.2d 646 (10th Cir. 1958); United States v. Aman, 210 F.2d 344 (7th Cir. 1954) ; Leeby v. United States, 192 F.2d 331 (8th Cir. 1951); United States v. Goldstein, 168 F.2d 666 (2d Cir. 1948) ; Mobley v. State, 227 Ind. 335, 85 N.E.2d 489 (1949); State v. Johnson, 145 Me. 30, 71 A.2d 316 (1950); State v. Roseberry, 283 S.W.2d 652 (Mo. Ct. App. 1955) ; State v. Dildine, 41 Wash. 2d 614, 250 P.2d 951 (1952) ; Annot., 17 A.L.R. 910, 925 (1922). Sometimes civil and criminal cases are cited interchangeably in support of the waiver doctrine. See Rosenbloom v. United States, 259 F.2d 500, 502 (8th Cir. 1958).

10. E.g., Fed. R. Crm. P. 29 (a); Fla. Stat. Ann. $\$ 918.08$ (1944); Md. R. Proc. 738 (1958).

11. Rain v. State, 15 Ariz. 125, 133, 137 Pac. 550 (1913) ("Having voluntarily proceeded with the trial of the case ... we must consider the rohole case ...") (emphasis added); accord, T'Kach v. United States, 242 F.2d 937 (5th Cir. 1957) ; United States v. Goldstein, 168 F.2d 666 (2d Cir. 1948) ; State v. Howe, 69 Ariz. 199, 211 P.2d 467 (1949) ; Orange v. Commonwealth, 191 Va. 423 , 61 S.E.2d 267 (1950). 
prosecutor's case as it stood when the original motion was made. ${ }^{12}$ The waiver doctrine thus imposes an enormous responsibility on defense counsel whose motion is denied. In order to present his client's evidence to the jury he must waive what may be a legal ground for reversal. But if he rests his case, his client is almost certain to be convicted by the jury, ${ }^{13}$ so that everything will rest on the appeal. Obviously, a doctrine which imposes this kind of responsibility on the defense lawyer maximizes the role of counsel and prejudices the defendant who is badly represented.

Though appellate courts are insulated from some of the pressures affecting trial judges, ${ }^{14}$ a convicted defendant can rarely be certain of appellate reversal. Not only will the court construe the evidence in favor of the verdict, ${ }^{15}$ but the standard of sufficiency is unsettled in some jurisdictions ${ }^{16}$ and any standard is broad enough to permit contrary decisions on identical facts. ${ }^{17}$ If the

12. Wright v. State, 212 Miss. 491, 493, 54 So. $2 d$ 735, 736 (1951) ("he waived any error ... [in the denial of his motion] by putting on his proof."); accord, Maulding v. United States, 257 F.2d 56 (9th Cir. 1958); McDonough v. United States, 248 F.2d 725 (Sth Cir. 1957) ; United States v. Goldstein, 168 F.2d 666 (2d Cir. 1948).

13. A noted defense attorney states:

I think that today it has become a fact that unless a defendant takes the stand in a criminal case in his own defense his chances for acquittal are negligible.

Williams, The Trial of a Criminal Case, 29 N.Y.B.A. BuLL. 36, 41 (1957).

Williams asserts that over $99 \%$ of the criminal defendants in the federal courts who do not testify are convicted in jury trials. Id. at 42.

14. The appellate court is not subject to the community passions of a trial court nor does it work as closely with the prosecutor. For a discussion of the role the press can play in molding community responses to a trial, see Douglas, The Public Trial and a Free Press, 46 A.B.A.J. 840 (1960).

15. See, c.g., Goodman v. United States, 273 F.2d 853, 855 (8th Cir. 1960); United States v. Bucciferro, 274 F.2d 540, 541 (7th Cir. 1960) ; United States v. Tutino, 269 F.2d 488, 490 (2d Cir. 1959); State v. Milton, 85 Ariz. 69, 72, 331 P.2d 846, 848 (1958).

16. Compare People v. Huizenga, 34 Cal. 2d 669, 675-76, 213 P.2d 710, 713-14 (1950), with People v. McCree, 128 Cal. App. 2d 196, 201, 275 P.2d 95, 99 (Dist. Ct. App. 1954). See Note, Sufficiency of Circumestantial Evidence it a Criminal Case, 55 Colur. L. Rev. 549, 550 n.9 (1955), which collects cases laying down conflicting tests within the same jurisdiction.

17. The standard to be used in measuring the prosecutor's case varies between jurisdictions. The strictest and most common standard is that formulated in Isbell v. United States, 227 Fed. 788, 792 (Sth Cir. 1915), which requires the prosecution to negate "every other hypothesis but that of guilt." The most lenient standard is that promulgated by the Court of Appeals for the Second Circuit which requires only that there be "substantial evidence" of each element of the offense. See United States v. Sherman, 171 F.2d 619, 621 (2d Cir.), ccrt. denied, 337 U.S. 931 (1949); United States v. Andolschek, 142 F.2d 503, 504-05 (2d Cir. 1944) ; United States v. Feinberg, 140 F.2d 592, 594 (2d Cir.) cert. denied, 322 U.S. 726 (1944). Although it is difficult to distinguish between various formulations of the same standard and different standards, a third test lying somewhere between the Second Circuit and Isbell formulas was articulated in Curley v. United States, 160 F.2d 229,232 (D.C. Cir.), ccrt. denied, 331 U.S. 837 (1947), which requires the court to acquit if "reasonable juryman must necessarily have [a reasonable doubt]." See A. Goldstein, 
defendant elects to present his defense, on the other hand, he thereby waives any error in the denial of his motion and runs the risk of supplying evidence or innuendo that will contribute to his conviction by the jury. Incriminating evidence which may be elicited from a defense witness will be more damageing than similar evidence introduced by the prosecution $;^{18}$ impeachment of his witnesses may reflect adversely on the defendant $;^{19}$ his own testimony may be unpersuasive because of the emotional strain under which it is given ${ }^{20}$ any inconsistent or demonstrably false statement made by the defendant may be considered for impeachment purposes and sometimes as substantive evidence pointing to consciousness of guilt $;^{21}$ and if the defendant has a criminal record, that fact will inevitably be disclosed if he takes the stand.22 Evidence supplied by the defense may also lead an appellate court to sustain the con-

The State and The Accused: Balance of Advantage in Criminal Procedure, 69 Yale L.J. $1149,1160-61$ (1960), contrasting results on nearly identical facts where different tests were applied.

18. See, e.g., I. Goldstein, Trial Technique $\$ 546$ (1935) :

Admissions secured from the lips of opponent's client and his witnesses ordinarily have greater weight with the jury than does the testimony of one's own witnesses.

19. Cf. Ladd, Impeachnent of One's Own Witness-New Developnents, $4 \mathrm{U}$. Cur. L. REv. 69,79 (1936):

Under the adversary system ... it is somewhat natural to regard the witnesses as belonging to the party who calls them .... Consistent with this scheme is the thought that a party vouches for the persons he presents as witnesses. . . .

20. A person accused of crime may become confused and frightened under crossexamination. His memory may be faulty with respect to unanticipated collateral matter. He may be subject to impeachment for prior conviction of a felony. Other aspects of his behavior may be unfavorable if revealed. See Ratner, Consequences of Exercising the Privilege Against Self-Incrimination, 24 U. CHI. L. REv. 472, 487 (1957); see Hutchins \& Slesinger, Some Observations on the Law of Evidence-Conscionsness of Guilt, $77 \mathrm{U}$. PA. L. REv. 725, 734-40 (1929), where it is pointed out that the presence of authority quite often produces an appearance of guilt which has no relation to the crime charged but is rather a manifestation of a remote, imagined or entirely unconscious guilty feeling.

21. See Andrews v. United States, 157 F.2d 723 (5th Cir. 1946), cert. denied, 330 U.S. 821 (1947) ; People v. Tolson, 109 Cal. App. 2 d 579, 241 P.2d 32 (Dist. Ct. App. 1952); People v. Arnold, 43 Mich. 303, 5 N.W. 385 (1880). For other conduct which may be used to show consciousness of guilt, see generally Hutchins \& Slesinger, note 20 supra; 2 Wigmore, EVIDENCE $\$ \$ 273-76$ (3d ed. 1940).

22. Evidence of prior convictions are inadmissible although there are exceptions where the other crimes show motive, infent, a common plan, knowledge or the identity of the accused. See, e.g., People v. Molineux, 168 N.Y. 264, 61 N.E. 286 (1901) ; but once the accused testifies, prior convictions are freely admissible for impeachment purposes even when the prior crime was remote in time and nature, see People v. Buford, 396 Ill. 158, 71 N.E.2d 340 (1947), where a conviction for grand larceny under another name 15 years previously in another state was used to impeach the defendant in a trial for assault with a deadly weapon. The collateral issues and confusion which is likely to result from such impeachment is detailed in Morgan, Maguire \& Weinstein, Cases on Evidence 291-94 (4th ed. 1957). Unifora RuLe of EvIDENCE 21 would allow prior convictions to be used for impeachment only when they involve dishonesty or false statement. See generally, Comment, 70 Y ALE L.J. 763 (1961). 
viction even though it would have reversed the denial of the motion for acquittal if the defendant had rested at the close of the state's case. ${ }^{23}$

The defendant is most prejudiced by the waiver doctrine when evidence essential to his defense also plugs a gap in the prosecution's case-in-chief. This situation was exemplified by People v. Corbisiero. ${ }^{24}$ Defendant was indicted for murder after a neighbor died of a knife wound in front of the defendant's pastry shop. The prosecution proved the cause of death but failed to link the defendant to the crime. Defendant moved for acquittal at the close of the prosecution's case. The motion was denied. He then presented evidence of selfdefense. In so doing, however, his key witness not only linked the defendant to the crime but testified that the defendant actually stabbed the decedent. On appeal from the defendant's conviction, the prosecutor conceded that the evidence was insufficient at the close of his case-in-chief but urged the appellate court to consider the defendant's evidence to supply the deficiency. ${ }^{25}$ The court felt itself bound by the waiver doctrine. Therefore, in passing on the motion it had to consider all the evidence including that "disclosed by an accused in making his defense." 26 Nevertheless it reversed the conviction, saying that it would not "contrive a case against [the accused]."27 The Corbisiero court was faced with this problem: a defense witness had supplied the missing link in the prosecution's case; he had also given exculpatory testimony, the credibility of which was exclusively a matter for jury determination. ${ }^{28}$ If the waiver doctrine was inapplicable, the conviction would have to be reversed since there was insufficient evidence of guilt at the close of the prosecution's case-in-chief. Applying the waiver doctrine as the Corbisiero court said it would, however, there is absolutely no ground for reversal since there is sufficient evidence of guilt in the whole record and the exculpatory testimony was rejected by the jury. The court was able to reverse the conviction in this case only by writing an intellectually dishonest opinion which failed to resolve the problem posed.

The defendant may be prejudiced by an erroneous denial of his motion for acquittal even though his evidence will not fill a total void in the state's case. In the burglary case of Reynolds $v$. State, ${ }^{29}$ aside from the testimony of an accomplice which had to be corroborated, ${ }^{30}$ the defendant was linked to the

23. See notes $11 \& 12$ supra.

24. 290 N.Y. 191, 48 N.E.2d 481 (1943).

25. Id. at $193-94 ; 48$ N.E.2d at 482.

26. Id. at 194,48 N.E.2d at 482 .

27. Ibid.

28. See note 4 supra.

29. 14 Ariz. 302, 127 Pac. 731 (1912).

30. A conviction shall not be had on the testimony of an accomplice unless the accomplice is corroborated by other evidence which, in itself and without aid of the testimony of the accomplice, tends to connect the defendant with the commission of the offense. The corroboration is not sufficient if it merely shows the commission of the offense or the circumstances thereof.

Aruz. Rev. Stat. AnN. \$ 13-136 (1956). 
burglary only by evidence that men of his general description were seen loitering around the premises in question prior to the crime. Defendant moved for acquittal at the conclusion of the prosecution's case. The motion was denied. The defendant decided to rest without introducing evidence, thereby preserving his right to question on appeal the sufficiency of the prosecution's case. His conviction was reversed. Suppose, however, that the jurisdiction was one which adhered to the "substantial evidence" test, ${ }^{31}$ that even under that test the state's case-in-chief was inadequate, but that the defendant had offered evidence in his own defense instead of resting on his motion for acquittal. Suppose further that direct and cross-examination elicited from his witnesses evidence that (1) the defendant could not account for his activities on the night of the burglary, (2) he lived or worked near the scene of the crime and passed by it frequently, (3) he frequently associated with known felons and (4) he had himself been convicted of burglary on two previous occasions. Even when all this evidence is added to the state's case-in-chief it might not exclude every reasonable hypothesis except that of guilt, ${ }^{32}$ but it might justify denial of a motion for acquittal by a court following the substantial evidence test.

The waiver doctrine also undermines long-established rules requiring the state to introduce extrinsic evidence "corroborating" any confession, ${ }^{33}$ accomplice testimony, ${ }^{34}$ or possession evidence (in a burglary case) ${ }^{3 \overline{5}}$ essential to

31. See, e.g., United States v. Andolschek, 142 F.2d 503, 505 (2d Cir. 1944) ("The accused at bar do not argue that the evidence was not strong enough to support a verdict in a civil case, and it certainly was; that being true, our review ends"); and see note 17 supra.

32. This test is used by the majority of courts in circumstantial evidence cases. See, e.g., Isbell v. United States, 227 Fed. 788, 792 (8th Cir. 1915). See A. Goldstein, The State and the Accused: Balance of Advantage in Criminal Procedure, 69 YALE L.J. 1149, 1157-58 (1960).

33. The purpose of corroborating a confession is to prevent "errors in convictions based upon untrue confessions alone," [citing case] ; its foundation lies in a long history of judicial experience with confessions ... Confessions may be unreliable because they are coerced or induced, and although separate doctrines exclude involuntary confessions from consideration by the jury [citing cases] further caution is warranted because the accused may be unable to establish the involuntary nature of his statements. Moreover, though a statement may not be "involuntary" within the meaning of this exclusionary rule, still its reliability may be suspect if it is extracted from one under the pressure of police investigation-whose words may reflect the strain and confusion attending his predicament. . . .

Smith v. United States, 348 U.S. 147, 153 (1954).

Confessions must be corroborated in an overwhelming majority of state courts as well. See 7 Wigmore, Evidence $\$ \S 2070-72$ (3d ed. 1940); Annot., 127 A.L.R. 1130 (1940).

34. About half of the states require by statute that the testimony of an accomplice be corroborated. Cases and statutes are collected in 7 WIGMORE, EvioENCE $\$ 2056$ n.10 (Supp. 1959).

35. See, e.g., People v. Citrino, 46 Cal. 2d 284, 288, 294 P.2d 32, 35 (1956) ("Possession alone of property stolen in a burglary is not of itself sufficient to sustain the possessor's conviction of that burglary. There must be corroborating evidence of acts, conduct, or declarations of the accused tending to show guilt."). 
its case. In State v. Meadows, ${ }^{36}$ for example, the state built a case of arsonmurder around the defendant's confession and rested without establishing the incendiary origin of the fire by extrinsic evidence. Thus at the close of the prosecution's case under applicable state law 1) the confession should not have been considered since it was uncorroborated and 2) even if the confession was considered, the defendant should have been acquitted because the corpus delicti had not been independently established. ${ }^{37}$ The defendant, however, took the stand after his motion for judgment of acquittal was erroneously denied. In upholding his conviction on appeal, the Missouri court sanctioned the retroactive use of the defendant's testimony to corroborate the confession and independently to establish the corpus delicti. ${ }^{38}$ In Washington v. Arizo$n a^{30}$ the prosecution failed to present any independent evidence linking the defendant to the crime by way of corroborating the testimony of an alleged accomplice who was the only prosecution witness to incriminate the accused. On appeal, however, it was held that the defendant had supplied the necessary corroboration by admitting that he owned a coat which had been found at the scene of the crime. ${ }^{40}$ Here again, retroactive application of defense testimony was allowed to emasculate the corroboration requirement.

The combination of the waiver doctrine and judicial reluctance to grant motions of acquittal before the defense has been presented is very likely to prove extremely prejudicial when there are one or more co-defendants. Consider the classic case where "two sisters were indicted for murder, and there was evidence that they had both been in the room at the time the murder of the boy was committed; but the prosecution could not show that sister A had committed the offense or that sister B had committed the offense." 41 On the basis of such evidence a prosecutor should not survive a motion for acquittal. ${ }^{42}$ If the motion was erroneously denied and both defendants testified, however, they might turn on one another so that at the close of their testimony the jury would have evidence on which to convict either or both. A leading English

36. 330 Mo. 1020, 51 S.W.2d 1033 (1932).

37. The court accepted the defendant's contention that proof of the incendiary origin of the fire was an element of the corpus delicti which had to be established independently of the confession. Id. at 1025-26, 51 S.W.2d at 1036 .

38. We need not consider whether or not the state had made a sufficient showing of the corpus delicti when it closed its case in chief. Since defendant did not stand upon his demurrer offered at the close of the state's evidence, but offered evidence himself ... we see no reason why the rule that applies generally should not be applied here, viz., that the sufficiency of the evidence in the case, including the testimony of the defendant if that or other evidence offered by him aids or supplies deficiencies in the case made by the state in its evidence.

Id. at 1026,51 S.W.2d at 1036.
39. 46 Ariz. 446, 52 P.2d 476 (1935).
40. Id. at 450,52 P.2d at 478 .
41. Regina v. Abbott, [1955] 2 Al1 E.R. 899, 901 (C.C.A.).
42. See note 17 supra. 
case ${ }^{43}$ presents a variation of the problem. A businessman and his secretary were jointly tried for receiving money under false pretenses. The prosecutor proved the secretary actually received the money but failed to link her employer to the crime. After the employer's motion for acquittal was erroneously denied, both defendants testified. The secretary, presenting the only defense open to her, testified that she had received the money at the instance of her employer and with no intent to defraud. This testimony connected the employer to the crime and enabled the jury to convict both defendants. The appellate court considered the evidence at the time the motion was made and found it insufficient. Rejecting the waiver doctrine on the ground that the defendant had a right to have the charge dismissed as soon as the prosecution's case was found deficient, the court refused to consider the defendant's evidence and reversed the conviction. ${ }^{44}$

Why should a court which presumably is interested in increasing the precision of the criminal process-convicting the guilty and acquitting the innocent ${ }^{45}$-ever reverse the conviction of a defendant whose guilt, on the whole record, is quite apparent? A reversal in such a case decreases the precision of the process to the extent that an obviously guilty defendant is acquitted. This result, however, is justified if the general rule which requires acquittal in such a case has the effect of increasing the overall precision of the process. In the long run an inquisitorial system-one which relies primarily upon interrogation of the accused to determine guilt ${ }^{46}$-is far less precise than an accusatorial system-one in which the accuser must prove guilt without interrogation of the accused. ${ }^{47}$ This is so for a variety of reasons, primary among which is the highly questionable evidentiary value of the confession in general

43. Regina v. Abbott, [1955] 2 All E.R. 899 (C.C.A.).

44. Id. at 903. ("It was the prisoner's right to say that the case against him had collapsed, and that he was not called upon to answer"). Recognition by American courts of the need for dismissal at the first point in the trial where the failure of proof becomes obvious is found in cases which say dismissal at the close of the prosecutor's statement is on occasion appropriate. See United States v. Maryland Cooperative Milk Producers, 145 F. Supp. 151 (D.D.C. 1956) (dictum) ; McGuire v. United States, 152 F.2d 577, 580 (8th Cir. 1945) (dictum) ; State v. Karcher, 155 Ohio 253, 256, 98 N.E.2d 308, 310 (1951) (dictum).

45. If the court is to effectuate the multiple ends of the criminal law-isolation, rehabilitation and deterrence-it must assume the dual responsibility of acquitting the innocent as well as convicting the guility. For every innocent man convicted there may well be a guilty man at large. Isolation is thus thwarted, deterrence is diminished and resources for rehabilitation are likely to be wasted. See generally Hall, Objectives of Federal Criminal Procedural Revision, 51 Y ALE L.J. 723, 733-34 (1942).

46. For a description of the inquisitorial system and its development in France, see Howard, Crtminal Justice in England 383-85 (1931).

47. Ours is the accusatorial as opposed to the inquisitorial system. . . Under our system society carries the burden of proving its charge against the accused not out of his own mouth. It must establish its case, not by interrogation of the accused even under judicial safeguards, but by evidence independently secured through skillful investigation.

Watts v. Indiana, 338 U.S. 49, 54 (1949) (opinion of Frankfurther, J.). 
and the compulsory confession in particular. ${ }^{48}$ The long and unpleasant history of the inquisitorial system dictated its rejection by the founding fathers in favor of the accusatorial system. ${ }^{49}$ Any rule which encourages the prosecutor to prove guilt through the mouth of the accused and not through extrinsic evidence, however, undermines the accusatorial system and thereby reduces the precision of the process. The requirement that no case be brought unless the prosecutor can prove guilt extrinsically, without relying upon the accused, is inexorably interwoven into the accusatorial system and promotes the highest possible degree of precision in the system.

Entirely aside from a concern for the precision of the system, American courts sometimes free obviously guilty defendants in order to protect other values. For example, many courts exclude illegally obtained evidence not because the admission of such evidence would generally reduce precision, but solely to deter prosecutional officials from violating the right of privacy guaranteed by the fourth amendment. ${ }^{50}$ Similarly, contemporary society rec-

48. Many confessions are the product of at least psychological compulsion since it is the stock-in-trade of the police investigator. See O'HARA, FUNDANIENTALS OF CRIMINAL Investigation 99 (1956); Dienstein, Technics for the Crime Investigator 100 (1952). The inherently coercive nature of police interrogation sometimes has been a factor where courts have held a confession to be involuntary. See Ashcraft v. Tennessee, 322 U.S. 143 (1944).

Moreover, students of human behavior have thrown considerable doubt on the reliability of completely voluntary confessions. See Freud, Psychoanalysis and the Ascertainarent of Truth in Courts of Law 23, Collected Works, Vol. II (1956). Reik, The Compulsion to Confess 259-62, 265-66 (1959) ; Alexander \& Staub, The Criminal, The Judge and the Public 94-95, 139-49 (1956). Cf. Dosteyevsky, The Brothers Karamazov 757 (Mod. Lib. ed.)

49. This is manifested by various provisions of the Bill of Rights. The fifth amendment privilege against self-incrimination negates completely reliance on inquisition. Furthermore, the right to confrontation and compulsory process guaranteed by the sixth amendment and the right to bail provided for in the eighth amendment are all inconsistent with the inquisttorial system. See Howard, note 46 supra.

50. If letters and private documents can thus be seized [without a warrant for search or arrest] and held and used in evidence against a citizen accused of an offense, the protection of the Fourth Amendment ... might as well be stricken from the Constitution. ...

Weeks v. United States, 232 U.S. 383, 393 (1914). The fourteenth amendment, however, does not preclude the use of illegally obtained evidence in state courts. Wolf v. Colorado, 338 U.S. 25 (1949), although illegally seized evidence obtained by state officers is no longer admissible in a federal court. Elkins v. United States, 364 U.S. 206 (1960). The "exclusionary rule" is gaining ground in state courts. See Table I, Appendix to Elkins v. United States, supra, many of which are motivated by the same factors which led to the Weeks decision. See, c.g., People v. Cahan, 44 Cal. 2d 434, 282 P.2d 905 (1955).

We have been compelled [to hold such evidence inadmissible] because other remedies have completely failed to secure compliance with the constitutional provisions on the part of police officers with the attendant result that the courts under the old rule have been constantly required to participate in, and in effect condone, the lawless activities of law enforcement officials.

Id. at 445,282 P.2d at $911-12$. 
ognizes as a separate value the right of an individual, whether guilty or innocent, not to be inconvenienced and stigmatized by a criminal prosecution ${ }^{\text {t1 }}$ unless the prosecutor has, at the time of the trial, sufficient independent evidence of guilt to carry his case to the jury. Vigorous enforcement of defendant's right to immediate acquittal as soon as it is apparent that this burden has not been met might deter the reckless or malicious prosecutor from instituting a criminal proceeding on less than adequate evidence. But the waiver doctrine which effectively precludes appellate review of the denial of defendant's motion for acquittal at the close of the prosecution's case has the reverse effect. It actually encourages the prosecutor to bring a proceeding without adequate independent evidence of guilt in the hope of compelling the accused to testify and fill the evidentiary gaps.

The denial of a motion for acquittal at the close of the state's case-in-chief exerts considerable compulsion on the defendant to testify. Under the waiver doctrine, the defendant must choose either to rest in order to secure appellate review of the motion or to present a defense. As previously outlined, ${ }^{62}$ resting is hazardous at best. Often, therefore, the accused will offer a defense in the hope of securing an acquittal by the jury. Yet a defendant stands little chance of acquittal unless he testifies. ${ }^{53}$ Some complusion to take the witness stand is present, therefore, even when the motion for acquittal is properly denied. Complusion in that case, however, occurs after the prosecution has proved guilt by independant evidence. Adamson $v$. California ${ }^{54}$ held that a state prosecutor could add to this compulsion by commenting if the accused fails to testify. ${ }^{55}$ In Adamson, however, the state had presented sufficient extrinsic evidence of guilt to carry the case to the jury ${ }^{56}$ before compulsion occurred and, therefore, there was no possibility that the defendant's testimony would supply a deficiency in the state's case. But where a motion for acquittal is erroneously denied, the compulsion to testify is exerted before the prosecution has proven guilt. Even worse, the waiver doctrine sanctions the use of defense evidence, evidence which would not have been presented but for the erroneous

51. "I must say that, as a litigant, I should dread a law suit beyond almost anything short of sickness or death." Hand, The Deficiencies of Trials to Reach the Heart of the Matter, 3 LeCTURES ON LEgAL Topics 89, 105 (1926). Cannot it be assumed that the strain is compounded for a criminal defendant? The certainty and degree of moral opprobrium, of course, will vary with the offense and the community in which it is committed.

52. See notes 15,16 and 17 supra and accompanying text.

53. See note 13 supra.

54. 332 U.S. 46 (1947).

55. Most observers believe the jury will draw inferences unfavorable to the accused even without comment by prosecutor or judge on his failure to testify. See WIGMore, EVtoence \$§ 2272, 2273 (3d ed. 1940); Bruce, The Right to Comment on the Failure of the Defendant to Testify, 31 Mrce. L. Rev. 226 (1932) ; Note, 25 FordHaMr L. Rev. 381 (1956); Comment, 6 DE PAUL L. REv. 83 (1956). Six states permit comment on the defendant's failure to take the stand: New Jersey, Ohio, Vermont, Connecticut, Iowa and California.

56. 332 U.S. 46, 52 (1947). 
ruling, to support the defendant's conviction. As the New Jersey court noted in rejecting the doctrine, 57 this comes "perilously near compelling the accused to convict himself." 58 Whether or not compulsion to testify under these circumstances-before the state has met its burden-technically contravenes the privilege against self-incrimination, ${ }^{59}$ it is certainly offensive to its spirit and to the fundamental precept that the prosecutor must prove his case by evidence "independently secured." 0

Erroneous denial of a motion for acquittal at the close of the prosecution's case is encouraged by a variety of factors in the present system. There is seldom appellate review of judgments of acquittal because in most jurisdictions the state cannot appeal. ${ }^{61}$ Consequently, trial judges know that they bear the ultimate responsibility if prosecutions are terminated midway in the trial. Furthermore, they are aware that they will probably have two subsequent opportunities to review denial of the motion for acquittal-when the motion is renewed at the close of all the evidence, and when the defendant seeks judgment n.o.v. ${ }^{62}$ This naturally tends to increase the reluctance to grant a nonreviewable acquittal before all available evidence is in the record. Moreover, judges' institutional familiarity with prosecutors and their deference toward public officials attempting to perform their duty may militate against early dismissals. ${ }^{63}$

57. State v. Bacheller, 89 N.J.L. 433, 98 Atl. 829 (1916).

58. Id. at 436, 98 Atl. at 830 .

59. U.S. Const., amend. V. All but two state constitutions have analogous provisions. 8 WIGMORE, EVIDENCE $\$ 2252$ (3d ed. 1940).

60. See Watts v. Indiana, 338 U.S. 49, 54 (1949).

61. Only three states allow the state to appeal from an acquittal: Connecticut, Cons. Gen. Stat. Ann. § 54-96 (1958), State v. Lee, 65 Conn. 265, 30 Atl. 1110 (1894); Vermont, Vt. Stat. Ann. tit. 13, § 7403 (1958), State v. Felch, 92 Vt. 477, 105 Atl. 23 (1918); Wisconsin, Wis. Stat. Ann. § 958.12(d) (1958), State v. Witte, 243 Wis. 423, 10 N.W.2d 117 (1943), although the trial orders that may be appealed by the state vary considerably. Compare 18 U.S.C. 373 (1951) (United States may appeal from a decision dismissing an indictment or information and from a decision arresting judgment) with CAL. PEN. CODE § 1238 (state may appeal from an order dismissing an indictment or information, from an order granting a new trial, from an order made after judgment affecting the substantial rights of the state and from an order modifying the verdict or reducing the degree of the offense or the punishment imposed.

62. See, e.g., FED. R. CRIM. P. 29(b).

63. The empathy between the judge and prosecutor was greater during the early period of the common law and was in part responsible for the development of trial by jury.

Our law has wisely placed this strong and twofold barrier, of a presentment [by grand jury] and a trial by jury, between the liberties of the people and the prerogatives of the crown.

IV Blackstone's Commentaries 350 (Jones ed. 1916). See also Taft, The Administration of Criminal Lazw, 15 Yale L.J. 1, 4 (1905) ; Plucknetr, A Concise History of the CoMMoN LAw 127 (4th ed. 1948) (juries occasionally punished for acquitting defendant in a political trial). But see Orfield, Crimanal Procedure from Arrest to Appeal 408-13 (1947). 
As presently administered, the motion for acquittal at the close of the government's case-in-chief is ineffectual. The mechanics of the present procedural system lead trial judges to deny the motion and defendants to go forward with their evidence. ${ }^{64}$ If the motion is to fulfill its function of early dismissal of prosecutions based on insufficient evidence, there must be appellate supervision of the motion's denial. In almost every jurisdiction, however, the waiver doctrine precludes review. ${ }^{65}$ Despite the near universal acceptance of the doctrine, there are very few cases or commentators that have discussed its policy basis. The arguments made on its behalf are unconvincing. Some courts have called the error "harmless" where the accused discloses incriminating facts. ${ }^{66}$ Since such testimony would not have been presented had there been no error, it can be labeled harmless only if it is assumed that all errors are harmless where the defendant appears guilty to the appellate court. This, however, has never been the rule. Other courts have said that the error is waived because the defendant could have rested and since he "voluntarily" offered his proof, he has no complaint. ${ }^{67}$ Since the defendant has almost no chance of an acquittal by the jury if he remains silent after the government rests, ${ }^{68}$ and since he has little assurance of appellate reversal, ${ }^{68}$ it is deceptive to say that the defendant proceeds voluntarily. Two other factors not articulated in the opinions probably underlie the doctrine. First, the waiver doctrine was already familiar in the civil context before it became a part of the criminal process and it was borrowed without the benefit of real analysis, ${ }^{70}$ and, second, appellate courts motivated by a desire to increase the precision of the process are reluctant to discharge a defendant whose guilt is apparent on the whole record. But the recognized differences between the criminal and the civil process require that any interchange of procedural rules be accompanied by

64. See notes 15-17 supra and accompanying text.

65. See note 9 supra.

66. United States v. Goldstein, 168 F.2d 666, 670 (2d Cir. 1948) ("[H]e cannot take advantage of an error [in denying his motion] if he makes that error harmless.") ; People v. Crane, 34 Cal. App. 760, 765, 168 Pac. 1055, 1057 (1917) ("[T] he court erred in denying appellant's motion ... and such error is reversible ... . But the required evidence was thereafter supplied by the defendant himself, and we cannot say, therefore ... that defendant was prejudiced in said ruling.").

67. Leyer v. United States, 183 Fed. 102, 104 (2d Cir. 1910) ("[I]t is immaterial that evidence essential to conviction was voluntarily introduced by the defendant himself. . . . Defendant was not compelled to go forward. ... [H]e could quite safely rest upon his exception ....").

68. See note 13 supra.

69. See notes 15-17 supra and accompanying text.

70. State v. Goldstein, 168 F.2d 666, 670 (2d Cir. 1948) ("What was said in Bogk v. Cassert [149 U.S. 17 (1893)] [a civil case] . . . is equally applicable now."); Leyer v. United States, 183 Fed. 102, 104 (2d Cir. 1910) ("It is well-settled ... that an exception to a refusal to direct a verdict ... is waived, if defendant thereafter proceeds to put in proof." [citing civil case]) ; State v. Meadows, 330 Mo. 1020, 1026, 51 S.W.2d 1033, 1036 (1932) ("we see no reason why the rule that applies generally should not be applied here"). 
careful analysis. And as previously demonstrated, acquittal of the guilty in any given case may, by insuring the efficacy of the accusatorial system, increase the overall precision of the criminal process. ${ }^{71}$ Moreover, the abolition of the waiver doctrine and the resultant supervision over motions to acquit would maximize the societal value of not having prosecutions brought without sufficient independent evidence of guilt.

Collateral support for the abolition of the waiver doctrine can be found in Jackson $v$. United States. ${ }^{72}$ The court held that a defendant who moved for acquittal at the close of the prosecution's case had a right to a ruling on this motion before he elected whether or not to present a defense; it therefore reversed an attempt by the trial judge to reserve decision on the motion until both sides had rested. The reversal was grounded on the court's interpretation of the Federal Rules of Criminal Procedure ${ }^{73}$ and its belief that the motion for acquittal "would be a futile thing if the court could reserve its ruling and force the defendant to an election between resting and being deprived of the benefit of the motion."74 This decision necessarily implies that the motion for acquittal should be granted if the evidence against the accused is insufficient at the time the motion is made. Paradoxically, however, the Jackson court also reaffirmed the waiver doctrine, ${ }^{75}$ failing to recognize that it allows the trial court effectively to "reserve" its decision by denying the motion.

If trial judges are to decide motions for acquittal made at the close of the state's case-in-chief in a fully disinterested manner, it may be necessary to balance the prospects of appeal from the granting and denial of such motions. When, as is generally true today, appeal can be taken if the motion is denied but not if it is granted, ${ }^{76}$ an extraneous factor is injected into the decisional process. Some judges may react to the disparity in appeal potential by automatically deciding close questions in favor of the accused, thereby avoiding the possibility of reversal. ${ }^{77}$ Others, realizing that the accused but not the state can appeal an erroneous ruling, may always deny the motion because they do not want to assume sole responsibility for terminating the prosecution with finality midway through the trial. ${ }^{78}$ Even though most judges

71. See text at notes 44,45 supra.

72. 250 F.2d 897 (5th Cir. 1958).

73. Id. at 901.

74. Ibid.

75. Ibid. ("The introduction of evidence after the denial of a motion made at the close of the prosecution's case waives any error in the denial of the motion.").

76. See note 60 supra.

77. See note 60 sipra and accompanying text. Most commentators favor state appeal. See generally Mayers \& Yarbrough, Bis Vexari, New Trials and Successive Prosecutions, 74 Harv. L. Rev. 1 (1960); Miller, Appeals by the State in Criminal Cases, 36 Yale L.J. 486 (1927) ; Note, $45 \mathrm{KY}$. L.J. 628 (1957); Note, 66 Y ALE L.J. 592 (1957); Note, 47 YALE L.J. 489 (1938). See also Comment, 65 YaLE L.J. 339 (1956).

78. See note 61 sipra and accompanying text. 
may be expected to withstand the procedural pressure exerted by the general inability of the state to appeal if the motion for acquittal is granted, that factor remains a latent source of error. It might therefore be advisable to grant the prosecution the right to appeal from a judgment of acquittal rendered at the close of its case-in-chief.

Opposition to government appeal has centered around its double jeopardy aspects, the possible added burden on the defendant, and the possibility of weakening the jury as a barrier between the state and the accused. ${ }^{70}$ Although the fifth amendment bars government appeal in the federal courts, ${ }^{80}$ no similar restriction is placed upon the states by the fourteenth amendment. ${ }^{31}$ Three states presently allow government appeal from all acquittals. ${ }^{82}$ Other state constitutions might be construed to allow government appeal from acquittals. ${ }^{83}$ The burden on criminal defendants generally might actually be lessened by government appeal. Not only does experience show that government appeals are rare even when permissible, ${ }^{84}$ but a more effective motion for acquittal, which presumably would result from government appeal, might save many defendants from being indicted and still others from bearing the burden of making a defense. When the state is successful, of course, the defendant would have to endure a second trial, but this is hardly worse than having to proceed with the trial after a motion for acquittal has been erroneously denied. More-

79. See generally The Right of the State to Appeal Criminal Cases, 9 RuTGers L. Rev. 545, 553 (1955) ; Orfield, Criminal Apreai in America 71 (1939).

80. See Kepner v. United States, 195 U.S. 100 (1904), recently re-affirmed by Green v. United States, 355 U.S. 184 (1957).

81. Palko v. Connecticut, 302 U.S. 319 (1937), upheld a Connecticut statute allowing appeal by the state. Other cases indicate that although there may be some due process limitations on successive prosecutions, they do not result from any incorporation of the double jeopardy provisions of the fifth amendment. See Brock v. North Carolina, 344 U.S. 424 (1953) (no denial of due process by a second trial after mistrial declared on motion of prosecutor) ; Ciucci v. Illinois, 356 U.S. 571 (1958) (a majority of the court, by implication, said that where successive prosecutions amount to harassment, there is a violation of due process.)

82. See note 61 supra.

83. Wisconsin, one of the three jurisdictions which allows the state to appeal on acquittal, note 61 supra, has a constitutional prohibition against double jeopardy, WIs. Const. art. I, § 8, but State v. Witte, 243 Wis. 423,10 N.W.2d 117 (1943) held that a retrial after successful appeal by the state was not double jeopardy. The court followed the rationale of Justice Holmes' dissent in Kepner v. United States, 195 U.S. 100, 134 (1904), and reasoned that the accused was in "continuing jeopardy" until completion of a trial free of error. But see People v. Hill, 146 Cal. 145, 79 Pac. 845 (1905) ; People v. Forn, 70 Cal. 17, 11 Pac. 470 (1886).

84. Orfield, Criminal Appeals in America 63 (1939); See also Mayers \& Yarbrough, Bis Vexari: Nezw Trials and Successive Prosecutions, 74 HARv. L. REv. 1, 9 (1960), who point out that Connecticut requires the prosecution to request appeal at the time of the acquittal. Conn. Gen. Stat. Ann. \$ 54-96 (1958) requires the trial court's permission in order for the prosecutor to appeal. 
over, the burden of securing appellate reversal will now be on the government. So far as the integrity of the jury is concerned, allowing government appeal from a judicial acquittal can only result, if the state is successful, in the case eventually going to a jury-hardly a weakening of the barrier.

Theodore W. Phillipst

$\dagger$ Third year student, Yale Law School. 